\title{
Methods of Soil Management and Depths of Sowing in Corn Cultivation
}

\author{
Wendel Kaian Oliveira Moreira ${ }^{1,2}$, Fábio Daibes Borrajo ${ }^{2}$, Samara Ketely Almeida de Sousa ${ }^{2}$, \\ Geane Guedes Cardoso $^{2}$, Ana Laura da Silva Luz ${ }^{2}$, Raimundo Thiago Lima da Silva ${ }^{2,3}$, Alisson Daroda Cassiano ${ }^{1}$, \\ Rian Antonio dos Reis Ribeiro ${ }^{2,4}$, Leane Castro de Souza ${ }^{2,3}$ \& Cândido Ferreira de Olivera Neto ${ }^{2,3}$ \\ ${ }^{1}$ West Paraná State University, Cascavel, Paraná State, Brazil \\ ${ }^{2}$ Group of Studies on Biodiversity of Upper Plants, Federal Rural University of Amazônia, Belém, Pará, Brazil \\ ${ }^{3}$ Institute of Agrarian Sciences, Federal Rural University of Amazônia, Capitão Poço City, Pará, Brazil \\ ${ }^{4}$ Department of Agricultural Engineering \& Climate Sciences Viçosa, Federal University Viçosa, Viçosa, Brazil \\ Correspondence: Wendel Kaian Oliveira Moreira, Group of Studies on Biodiversity in Upper Plants, Federal \\ Rural University of Amazônia, Rua do Pau Amarelo, 68650000, Capitão Poço City, State of Pará, Brazil. Tel: \\ 55-31-91-3468-2155. E-mail: wendelmoreira21@outlook.com
}

Received: March 3, 2018

doi:10.5539/jas.v10n6p299
Accepted: April 18, 2018

Online Published: May 15, 2018

URL: https://doi.org/10.5539/jas.v10n6p299

\begin{abstract}
Corn (Zea mays L.) is one of the most cultivated grains in the world. It provides widely used products such as food, feed, raw materials for industry and ethanol, mainly due to the quantity and nature of its reserves accumulated in the grains. The objective of this research was to evaluate different depths of sowing and the use of different initial methods of soil preparation for growing corn. A randomized-complete blocks design was applied in a split plot with subsoiling, tillage, rotary hoe, ploughing, manual weeding and three sowing depths. Analysis of variance showed a significant difference $(\mathrm{p}<0.01)$ of stem diameter $(\mathrm{SD})$, plant height $(\mathrm{PH})$, root fresh mass (RFM), root dry mass (RDM), aerial dry mass (ADM), aerial fresh mass (AFM), while number of leaves (NL) showed no differences statistically. Regarding to stem diameter, the methods with subsoiling, ploughing and rotating hoe showed the best results. In relation to plant height, the treatments of subsoiling, tillage, ploughing and rotating hoe had the best performances. The use of the subsoiling method showed the best results between the characteristics of the plant and corn yield. The corn yield presented better yields with the subsoiled and rotary hoe preparation.
\end{abstract}

Keywords: agricultural mechanization, soil preparation, subsoiling, yield, Zea mays L.

\section{Introduction}

The corn cultivation stands out for its versatility in the food and energy industry. According to IEA (2017), the United States is the worldwide largest producer and exporter. This is the third most produced crop in the world and its production its production impels the global agriculture market.

In this sense, studies should be conducted to improve production systems, and the quality of sowing is an important step for the success of the productivity of an agricultural crop (Francetto et al., 2015). Thus, sowing techniques contributes to a better distribution of the seeds in the soil and combined with the proper deposition depth results in a uniform stand of the plants (Almeida et al., 2010). For this reason, this step requires greater perfection in its execution, since it compromises the profitability of the agricultural activity (Ros et al., 2011). This implies that seeds should be deposited at a depth that allows optimal contact with moist soil, resulting in a satisfactory germination rate.

Therefore, this paper aims to analyze the development and productivity of corn cultivation under the mechanization effect on initial soil preparation and depths of sowing. In a study, Bottega et al. (2014) report that sowing concentrates in a depth margin of 3 to $7 \mathrm{~cm}$, and the average soil depth is $5 \mathrm{~cm}$. However, Prado, Coan, and Villar (2002) analyzed three levels of sowing depth $(3,5$, and $7 \mathrm{~cm})$ in the emergence and initial growth of corn and found that in relation to the rate of emergence the intermediate level of $5 \mathrm{~cm}$ showed a higher rate of emergence velocity, that is, for corn crop the depth of sowing should not be shallow or deep so that there is 
adequate germination. Already Souza (2016) in a study with different sowing depths obtained better productivity results when the seeds were $4 \mathrm{~cm}$ deep.

In addition to the depth factor, productivity is often compromised by the application of inadequate practices in which the soil is submitted from its preparation to harvest (Suzuki \& Alves, 2004). Thus, mechanized soil preparation is performed with the aim of improving and creating favorable conditions for germination and root growth of the crops (Deperon Júnior et al., 2016). Faced with this aspect, the methods of preparation can vary from those that cause intense mobilization of the soil, like the conventional preparation, until the so-called conservationist preparations.

According to Carvalho Filho et al. (2007) there is appropriate equipment, for each situation of which the ground is. Souza (2017) verified that the use of the chisel plow reduced compacted layers of the soil, which provided better yields to corn crops, thus improving the physical attributes of the soil. The use of offset disk showed greater soil degradation and its consecutive use should be avoided. Subsoiling is an effective technique for breaking compacted layers generated by conventional long-term and no-tillage crops (Liu et al., 2016). Studies by Carvalho Filho et al. (2006) observed that systems of preparation with disk plow provided a larger initial soybean stand, when compared to those in the ripper and rotary hoe.

In view of the above, the present research aims to analyze the development and productivity of the corn crop under the effect of mechanization in the initial preparation of the soil and depths of sowing.

\section{Methods}

\subsection{Field Sites and Material Description}

The experiment was conducted in the experimental field of the Federal Rural University of the Amazon (Ufra), Campus of Capitão Poço. The municipality of Capitão Poço presents thermal amplitude from 25.7 to $26.9^{\circ} \mathrm{C}$, with an annual average of $26.2{ }^{\circ} \mathrm{C}$ and only $1.2{ }^{\circ} \mathrm{C}$ of variation (Silva et al., 2011a). According to Köppen climate classification, this region is Am type (Oliveira et al., 2016).

During cultivation cycle (143 days) there was a total of $573 \mathrm{~mm}$ of precipitation, the temperature varied in average $25.47,33.08{ }^{\circ} \mathrm{C}$, corresponding to the units of maximum and minimum measures, respectively. In the studied region, the maximum temperature was $34.1^{\circ} \mathrm{C}$ in January and also the minimum temperature of $20.90{ }^{\circ} \mathrm{C}$ according to data collected from the automatic station of National Institute of Meteorology (Figure1).

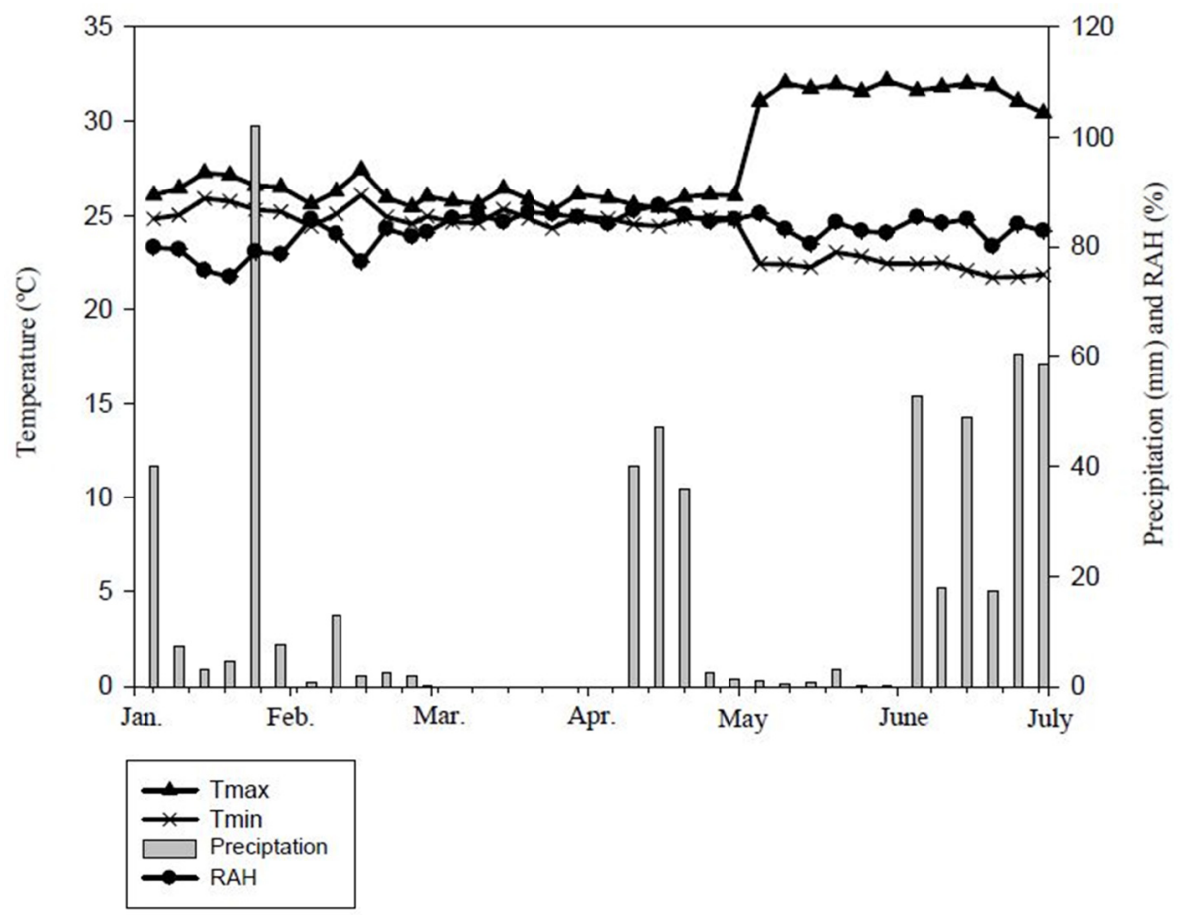

Figure 1. Climatic data of maximum temperatures (Tmax), minimum (Tmin), relative air humidity [RAH (\%)] and precipitation $(\mathrm{mm})$. Source: automatic weather station, INMET 2015 


\subsection{Experimental Design}

The soil used presents characteristics of Yellow Latosol EMBRAPA (2013), with chemical conditions presented in Table 1.

Table 1. Soil chemical and physical conditions

\begin{tabular}{ll|ll}
\hline Characteristics & Contents & Characteristics & Contents \\
\hline $\mathrm{pH}$ & 4.5 & $\mathrm{C}\left(\mathrm{g} \mathrm{Kg}^{-1}\right)$ & 8.52 \\
Eletrical Conductivity $\left(\mathrm{ds} \mathrm{m}^{-1}\right)$ & 0.25 & $\mathrm{C} / \mathrm{N}$ & 10 \\
$\mathrm{Ca}^{2+}\left(\mathrm{cmol}_{\mathrm{c}} \mathrm{Kg}^{-1}\right)$ & 0.7 & $\mathrm{OM}\left(\mathrm{g} \mathrm{Kg}^{-1}\right)$ & 14.69 \\
$\mathrm{Mg}^{2+}\left(\mathrm{cmol}_{\mathrm{c}} \mathrm{Kg}^{-1}\right)$ & 0.6 & $\mathrm{~V}(\%)$ & 24 \\
$\mathrm{Na}^{+}\left(\mathrm{cmol}_{\mathrm{c}} \mathrm{Kg}^{-1}\right)$ & 0.05 & $\mathrm{~m}(\%)$ & 36 \\
$\mathrm{~K}^{+}\left(\mathrm{cmol}_{ } \mathrm{Kg}^{-1}\right)$ & 0.09 & $\mathrm{P}-\mathrm{ass}(\mathrm{mg} \mathrm{Kg}$ & \\
$\mathrm{H}^{+}+\mathrm{Al}^{3+}\left(\mathrm{cmol}_{\mathrm{c}} \mathrm{Kg}^{-1}\right)$ & 4.46 & $\theta_{\mathrm{FC}}(100 \mathrm{kPa})(\%)$ & 8 \\
$\mathrm{Al}^{3+}\left(\mathrm{cmol}_{\mathrm{c}} \mathrm{Kg}^{-1}\right)$ & 0.8 & $\theta_{\mathrm{WP}}(1500 \mathrm{kPa})(\%)$ & 17.82 \\
$\mathrm{~S}\left(\mathrm{cmol}_{\mathrm{c}} \mathrm{Kg}^{-1}\right)$ & 1.4 & $\mathrm{ds}\left(\mathrm{g} \mathrm{cm}^{-3}\right)$ & 7.13 \\
$\mathrm{~T}\left(\mathrm{cmol}_{\mathrm{c}} \mathrm{Kg}^{-1}\right)$ & 5.9 & $\mathrm{dp}\left(\mathrm{g} \mathrm{cm}^{-3}\right)$ & 1.93 \\
$\mathrm{~N}\left(\mathrm{~g} \mathrm{Kg}^{-1}\right)$ & 0.86 & $\mathrm{CEC}\left(\mathrm{cmol}_{\mathrm{c}} \mathrm{Kg}^{-1}\right)$ & 2.85 \\
\hline
\end{tabular}

Note. $\mathrm{pH}: \mathrm{pH}$ in water, 1:2.5 v/v according to the methodology of Embrapa (1997); OM: organic matter (Walkley-Black method); $\mathrm{pH}=$ hydrogenation potential; $\mathrm{Ca}=$ calcium; $\mathrm{Mg}=$ magnesium; $\mathrm{Na}=$ sodium; $\mathrm{K}=$ potassium; $\mathrm{Al}=$ aluminum; $\mathrm{S}=$ sulfur; $\mathrm{T}=\mathrm{CEC}$ total; $\mathrm{N}=$ nitrogen; $\mathrm{C}=$ carbon; $\mathrm{C} / \mathrm{N}=$ carbon/nitrogen; $\mathrm{OM}=$ organic matter; $\mathrm{V}=$ base saturation; $\mathrm{m}=$ saturation by aluminum; $\mathrm{P}$-ass $=$ phosphorus assimilable; $\theta_{\mathrm{FC}}=$ soil water content at field capacity at $100 \mathrm{kPa} ; \theta_{\mathrm{WP}}=$ soil water content at wilting point at $1500 \mathrm{kPa}$; ds $=$ soil bulk density; $\mathrm{dp}=$ density of particles; CEC, cation exchange capacity.

The experiment began on January 22, 2015, with the help of a New Holland tractor, model LT75, $4 \times 2$ TDA, with auxiliary front-wheel drive activated, and nominal power of $78 \mathrm{cv}$ and power take-off $540 \mathrm{rpm}$, operating in the average velocity of $5 \mathrm{~km} \mathrm{~h}^{-1}$, in which there was the coupling of the implements and the execution of the different initial soil preparation methods followed by liming in all the blocks.

After the desacidification period, the sowing was done manually with 1 meter long wooden rods, and a metallic insert was added so that it does not exceed the required depth; it was performed on February 21, 2015. The fertilization of the foundation and replacement according to Cravo et al. (2007) with the appropriate proportions of $90 \mathrm{~kg} \mathrm{ha}^{-1}$ of $\mathrm{P}_{2} \mathrm{O}_{5} ; 60 \mathrm{~kg} \mathrm{ha}^{-1}$ of $\mathrm{KCl}$; and $80 \mathrm{~kg} \mathrm{ha}^{-1}$ of $\mathrm{N}$.

The cultivar used was BRS 205-hybrid, with spacing of $0.15 \mathrm{~m} \times 1 \mathrm{~m}$ between plants and lines. The corn harvested was made manually in all useful parcels (without border), and was completed on June 13, 2015. The size of each experimental unit was $6 \mathrm{~m} \times 6 \mathrm{~m}$, with an area of $36 \mathrm{~m}^{2}$, the total size of one block $22 \mathrm{~m}$ long and 38 $\mathrm{m}$ wide, totaling $836 \mathrm{~m}^{2}$.

The experimental design applied in blocks with split parcel scheme $(5 \times 3)$ and with 3 repetitions. The treatments were performed according to the following factors, 5 methods of initial preparation of the soil (main parcel), being them: Subsoiler (SB); rotary hoe (RH); Leveling disc harrow (LDH); disc plow (DP); manual weeding (MW) (Table 2), and the sub-parcel had 3 depths of sowings; $1.5 \mathrm{~cm} ; 3.0 \mathrm{~cm} ; 4.5 \mathrm{~cm}$, and to determine the different depths of sowing, it was used as base the ideal depth indicated by EMBRAPA (2010). 
Table 2. Characteristics of the equipment used in the initial preparation of the soil

\begin{tabular}{|c|c|c|c|}
\hline Implements & Brand & Model & Characteristics of the implements \\
\hline Subsoiler & Köhler & & $\begin{array}{l}7 \text { claws and } 7 \text { discs of } 18 \text { ", with depth of work } 0.20 \text { to } 0.45 \mathrm{~m}, 2500 \mathrm{~kg} \text { weight } \\
\text { and power of the required tractor of } 75 \text { to } 100 \mathrm{cv} \text {. }\end{array}$ \\
\hline Leveling Disc Harrow & Baldan & NVCR & $\begin{array}{l}32 \mathrm{discs} \text {, of } 20 \text { "- } 22 \text { " spaced at } 175 \mathrm{~mm} \text {, its working depth ranges from } 50 \mathrm{~mm} \\
\text { to } 150 \mathrm{~mm} \text {, approximate weight } 1384 \mathrm{~kg} \text { and its demand of } 75 \mathrm{cv} \text {. }\end{array}$ \\
\hline Rotary Hoe & Agritech Lavrale & RSFE 150 & $\begin{array}{l}\text { It presents a displacement of } 0.45 \mathrm{~m} \text { and its maximum depth of reach in the } \\
\text { soil profile is of } 0.25 \mathrm{~m} \text {, the implement presents } 36 \text { hoes with total weight } \\
550 \mathrm{~kg} \text {, its requirement and power for its operation as the manual is of } 50-75 \\
\mathrm{cv} \text { and rotation of } 170 / 230 \mathrm{rpm} \text {. }\end{array}$ \\
\hline Disc Plow & Baldan & AFL & $\begin{array}{l}\text { Equipped with } 3 \text { discs of } 28 \text {, weighing approximately } 325 \mathrm{~kg} \text {, requiring } \\
\text { power of } 40-45 \mathrm{Hp} \text {. }\end{array}$ \\
\hline Manual Weeding & Tramontina & - & Iron blade of $38 \mathrm{~mm}$ and wooden handle $150 \mathrm{~mm}$. \\
\hline
\end{tabular}

The biometric evaluations were determined by means of digital calipers with $0.001 \mathrm{~mm}$ precision; for the height parameter of the plant it was used a tape measure of $5 \mathrm{~m}$ and ruler with the same numerical scale, and the mass variables were measured by means of the precision decimal scale of $0.01 \mathrm{~g}$ brand: BEL series S1502.

Before the last stage of physiological maturation of the plant (VT), on May 26, 2015, the biometric evaluation of 10 plants per sub-parcel was carried out (Santo et al., 2014), making a total of 450 plants representing the total area. Thus, it was verified the diameter of stem [SD (cm)] measured between the first and second node; height of the plant $[\mathrm{PH}(\mathrm{m})]$ taking the measure of the vertical axis between the ground level to the highest part of the plant, the number of leaves (NL) performed by counting the true leaves.

For the production analysis, it was carried out at the stage $\left(\mathrm{R}_{6}\right)$, where it were determined the aerial fresh mass [AFM $\left(\mathrm{g} /\right.$ plant $\left.\left.^{-1}\right)\right]$, aerial dry mass [ADM $\left(\mathrm{g} /\right.$ plant $\left.\left.^{-1}\right)\right]$, root fresh mass [RFM $\left.\left(\mathrm{g} / \mathrm{plant}^{-1}\right)\right]$, root dry mass [RDM $\left.\left(\mathrm{g} / \mathrm{plant}^{-1}\right)\right]$. These variables were separated in aerial part (leaves and stem) and root system, being weighed and conditioned in a forced circulation greenhouse with a temperature of $65^{\circ} \mathrm{C}$ until reaching constant mass.

It was evaluated also the number of rows per spike (NRS), 100 grains mass [100GM $\left.\left(\mathrm{g} / \mathrm{spike}^{-1}\right)\right]$, spike mass [SM $\left.\left(\mathrm{g} / \mathrm{spike}^{-1}\right)\right]$ haystack corncob mass [HCM $\left(\mathrm{g} /\right.$ spike $\left.\left.^{-1}\right)\right]$, spike diameter [SD $\left.(\mathrm{cm})\right]$, length of corncob [LC $(\mathrm{cm})]$, corncob of diameter [CD $(\mathrm{cm})]$, corncob mass [CM $\left.\left(\mathrm{g} / \mathrm{spike}^{-1}\right)\right]$, fresh mass of the grain per spike [FMGS $\left.\left(\mathrm{g} / \mathrm{spike}^{-1}\right)\right]$, they were submitted to the average of thirty units per block collected. The corn yield $\left(\mathrm{kg} \mathrm{h}^{-1}\right)$ was determined by means of a sampling of 30 units of each sub-parcel with application of the method to representation in $\mathrm{ha}^{-1}$. For all the cases, yield moisture content was correct to $13 \%$.

\subsection{Analytical Procedures}

The experimental data were submitted to the Shapiro-Wilk (1965) and Bartlet tests (1937) $(p>0.01)$ to verify the normality and homoscedasticity. Data that did not meet ANOVA assumptions were transformed by the method of Box-Cox (Box \& Cox, 1964). Taking into account the basic assumptions the set of values were submitted to ANOVA and Scott-Knott clustering test, with probability of 5\% of error, performed in Sisvar Software (Ferreira, 2011).

\section{Results and Discussion}

Analysis of variance showed a significant difference $(p<0.01)$ for the variables number of leaves $(N L)$, stem diameter (SD), plant height ( $\mathrm{PH})$, root fresh mass (RFM), root dry mass (RDM), aerial dry mass (ADM), aerial fresh mass (AFM) showed no differences statistic. As observed for the variable aerial dry mass presented interaction between the factors studied, with that the deployment was applied to analyze the influences between the factors (Table 3 ). 
Table 3. Analysis of variance number of leaves (NL), stem diameter (SD), plant height (PH), root fresh mass (RFM), root dry mass (RDM), aerial dry mass (ADM), aerial fresh mass (AFM) according to the soil preparation methods and depths of sowing in the corn cultivation

\begin{tabular}{|c|c|c|c|c|c|c|c|}
\hline & NL & SD & $\mathrm{PH}$ & RFM & $\mathrm{RDM}$ & $\mathrm{ADM}$ & AFM \\
\hline & un & \multicolumn{3}{|c|}{------------- cm ------------- } & 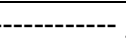 & $\mathrm{nt}^{-1}-\cdots$ & 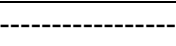 \\
\hline \multicolumn{8}{|l|}{ Soil Preparation } \\
\hline Subsoiler & $9.50 \mathrm{a}$ & $1.75 \mathrm{a}$ & $154.57 \mathrm{a}$ & $767.67 \mathrm{a}$ & $471.90 \mathrm{a}$ & $259.92 a$ & $690.03 \mathrm{a}$ \\
\hline Rotary Hoe & $9.37 \mathrm{a}$ & $1.60 \mathrm{a}$ & $146,28 \mathrm{a}$ & $775.38 \mathrm{a}$ & $457.77 \mathrm{a}$ & $180.23 b$ & $534.65 \mathrm{ab}$ \\
\hline Leveling Disc Harrow & $8.92 \mathrm{a}$ & $1.52 \mathrm{~b}$ & $139.42 \mathrm{a}$ & $593.67 \mathrm{a}$ & $349.71 \mathrm{a}$ & $225.03 \mathrm{a}$ & $650.75 \mathrm{a}$ \\
\hline Disc Plow & $9.21 \mathrm{a}$ & $1.65 \mathrm{a}$ & $149.68 \mathrm{a}$ & $769.10 \mathrm{a}$ & $468.50 \mathrm{a}$ & $236.93 a$ & $672.79 \mathrm{a}$ \\
\hline Manual Weeding & $8.90 \mathrm{a}$ & $1.37 \mathrm{~b}$ & $125.42 b$ & $314.09 b$ & $208.28 \mathrm{a}$ & $177.19 b$ & $411.33 \mathrm{~b}$ \\
\hline \multicolumn{8}{|l|}{ Depth of Sowing } \\
\hline $1.5 \mathrm{~cm}$ & $9.20 \mathrm{a}$ & $1.56 \mathrm{a}$ & $140.11 \mathrm{a}$ & $967.99 a$ & $431.05 \mathrm{a}$ & $198.46 \mathrm{a}$ & $577.01 \mathrm{a}$ \\
\hline $3.0 \mathrm{~cm}$ & $9.26 \mathrm{a}$ & $1.59 \mathrm{a}$ & $144.48 \mathrm{a}$ & $784.48 b$ & $271.53 b$ & $220.60 a$ & $601.58 \mathrm{a}$ \\
\hline $4.5 \mathrm{~cm}$ & $9.08 \mathrm{a}$ & $1.67 \mathrm{a}$ & $144.64 \mathrm{a}$ & $555.20 \mathrm{~b}$ & $271.12 b$ & $228.51 \mathrm{a}$ & $597.14 \mathrm{a}$ \\
\hline \multicolumn{4}{|l|}{ Source of Variation } & \multicolumn{4}{|c|}{ Medium Square } \\
\hline Block & 1.940 & 0.006 & 0.074 & 0.320 & 0.331 & 14619.1 & 24381.65 \\
\hline Soil Preparation (SP) & $0.646^{\mathrm{ns}}$ & $0.001 * *$ & $0.032 * *$ & $1.138 * *$ & $0.893 * *$ & $11775.9 * *$ & $124914.9 * *$ \\
\hline Error 1 & 0.280 & 0.0001 & 0.003 & 0.051 & 0.054 & 1548.3 & 10252.3 \\
\hline Depth of Sowing (DS) & $0.116^{*}$ & $0.00006^{\mathrm{ns}}$ & $0.003^{\mathrm{ns}}$ & $2.146^{* *}$ & $3.130 * *$ & $3639.4^{\mathrm{ns}}$ & $2570.8^{\mathrm{ns}}$ \\
\hline $\mathrm{SP} \times \mathrm{DS}$ & $0.461^{\mathrm{ns}}$ & $0.00003^{\mathrm{ns}}$ & $0.001^{\mathrm{ns}}$ & $0.165^{\mathrm{ns}}$ & $0.262^{\mathrm{ns}}$ & $766.9^{\text {ns }}$ & $33480.03^{* *}$ \\
\hline Error 2 & 0.439 & 0.0001 & 0.003 & 0.106 & 0.124 & 3683.6 & 10421.83 \\
\hline $\mathrm{CV}(\%)$ & 7.51 & 18.74 & 13.17 & 57.81 & 65.03 & $28 ., 96$ & 26.56 \\
\hline
\end{tabular}

Note. Averages followed by distinct letters differ from each other by Scott-Knott test at $5 \%$ of probability. CV (\%): Coefficient of variation.

** Significant at the 0.01 probability $(\mathrm{p}<0.01)$ by the F-test. * Significant at the 0.05 probability $(\mathrm{p}<0.05)$ by the F-test. NS, not significant $(\mathrm{p}>0.05)$ by the F-test.

Regarding to the diameter of the stem, the methods with subsoiling, plowing and rotary hoe showed the most significant results. These positive results can be attributed to better soil physical conditions provided by the above mentioned mechanized methods of soil preparation; which provided better spatial distributions of the root system, and made the use of soil resources more expressive. This fact was exemplified by Guan et al. (2014) where he reported that the potential of plants to obtain water and mineral nutrients from the soil is attributed mainly to their ability to develop extensive root systems. For the height parameter of the plant, the treatments of subsoiling, harrowing, plowing and rotating hoe obtained superior results when compared to manual weeding. Concerning the number of leaves, the results showed that they did not differ from one treatment to another (Table 3).

It is clear that among the variables root fresh mass, root dry mass and aerial dry mass; the worst results were found when manual weeding was applied, however, the variable aerial dry mass did not differ from the method with rotary hoe (Table 3 ).

The highest values for all the evaluated parameters were observed with the subsoiler use, this is probably due to the decompression of the soil promoted by this implement favoring the root development of the cultivation in study, causing it to reach deeper layers of the soil facilitating, as well, its root expansion to deeper horizons, and consequently, it has a greater absorption of water and mineral salts. The subsoiling is used to break up agricultural soil layers that have been compacted and to minimize their effects (Oliveira Filho et al., 2015)

The subsoiling is a practice of cultivation in depth that has become common is some regions of the country, serving to loosen compacted layers (Grotta et al., 2004). With only one passage of the implement, we have the positive reverse effect (decompressor) from the eventual operation performed in soil preparation (Silva et al., 2000).

With the compaction, there is the increase of the mechanical resistance of the soil and the reduction of porosity, pore continuity, permeability and availability of nutrients and water are reduced, reducing the root growth and development of the cultivation (Streck et al., 2004; Guaman et al., 2016; Beriso et al., 2012). 
Intensive agricultural machine traffic is the mainly responsible for increasing of density and resistance of the soil to the penetration, resulting in soil compaction and limited root development of the cultivation (Silva et al., 2011b), one of the physical attributes of the soil that can restrict or even impede the development of corn root is the soil resistance to the penetration (RSP) (Silva et al., 2013; Wolkowski \& Lowery, 2008).

Among the studied plantation depths, the variable root fresh and dry mass presented better production at $1.5 \mathrm{~cm}$ depth; the other variables did not present difference between the averages (Table 3). It is observed that the soil characteristics along with some physiological factors of the plant favored the best results in the closest layer of the soil surface; this may be related to root resistance when penetrating the deeper layers.

The more developed the root system, the more it will be the biomass production, besides promoting the decompression of the soil (Bertolini, 2006). A study carried out with the corn crop, Foloni et al 2003 detected that this plant did not present voracity in the rupture of compacted surface layers.

As shown in the analysis of variance in Table 2, the variable aerial fresh mass presented a significant interaction between treatments applied. When the seeding depth was analyzed according to the initial soil preparation, the mechanized methods presented the best results for the accumulation of aerial fresh mass (Table 4).

Table 4. Interaction aerial fresh mass (AFM) as a function for soil management methods and depth of sowing in corn cropping

\begin{tabular}{llll}
\hline \multirow{2}{*}{ Soil Management Method } & \multicolumn{3}{c}{ Aerial Fresh Mass $\left(\mathrm{g} / \mathrm{plant}^{-1}\right)$} \\
\cline { 2 - 4 } & $1.5 \mathrm{~cm}$ & $3.0 \mathrm{~cm}$ & $4.5 \mathrm{~cm}$ \\
\hline Subsoiler & $585.39 \mathrm{bA}$ & $779.22 \mathrm{aA}$ & $705.48 \mathrm{aA}$ \\
Rotary Hoe & $539.34 \mathrm{bA}$ & $498.60 \mathrm{bA}$ & $566.02 \mathrm{aA}$ \\
Leveling Disc Harrow & $549.94 \mathrm{bA}$ & $756.00 \mathrm{aA}$ & $646.31 \mathrm{aA}$ \\
Disc Plow & $838.10 \mathrm{aA}$ & $540.20 \mathrm{bB}$ & $640.06 \mathrm{aB}$ \\
Manual Weeding & $372.30 \mathrm{cA}$ & $433.20 \mathrm{bA}$ & $427.83 \mathrm{bA}$ \\
\hline
\end{tabular}

Note. Averages followed by distinct letters differ from each other in the column (lower-case) and in the lines (upper-case) by the Scott-Knott test at $5 \%$ probability.

Sowing depth of $1.5 \mathrm{~cm}$ from soil showed a significant result when the soil was prepared with the disc plow. However, the other preparations were not influenced when submitted to the different depths for the aerial fresh mass accumulation (Table 4).

When compared the depths of sowing, it can be observed that depth of $1.5 \mathrm{~cm}$ presented a higher production of aerial fresh mass when prepared with disc plow. On the other hand, the sowing depth of $3 \mathrm{~cm}$ was superior, when applied the subsoiling and leveling disc harrow. And yet, corn seeds when submitted to $4.5 \mathrm{~cm}$ of depth show that all mechanized methods were better than manual weeding (Table 4).

In Table 5, the characters number of rows per spike and length of corncob presented significant statistical differences for the forms of soil preparation, where the highest found and observed values for the number of rows per spikes obtained with the subsoiling, leveling disc harrow and disc plow, while the length of corncob was observed with subsoiler and rotary hoe. 
Table 5. Number of rows per spike (NRS), 100 grains mass (100GM), spike mass (SM), haystack corncob mass (HCM), cob mass (CM), fresh mass of the grain per spike (FMGS), spike diameter (SD), length of corncob (LC) corncob of diameter (DC), as a function of soil preparation methods and depth of sowing in the corn cultivation

\begin{tabular}{|c|c|c|c|c|c|c|c|c|c|}
\hline & NRS & 100GM & SM & $\mathrm{HCM}$ & $\mathrm{CM}$ & FMGS & $\mathrm{SD}$ & LC & $\mathrm{CD}$ \\
\hline & & ---------- & ----------. & $--\mathrm{g} / \mathrm{spi}$ & 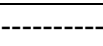 & 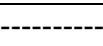 & ---------- & --- $\mathrm{cm} \mathrm{--}$ & --- \\
\hline \multicolumn{10}{|l|}{ Soil Preparation } \\
\hline Subsoiler & $13.12 \mathrm{a}$ & $24.09 \mathrm{a}$ & $75.64 \mathrm{a}$ & $9.17 \mathrm{a}$ & $13.48 \mathrm{a}$ & $52.99 \mathrm{a}$ & $3.86 \mathrm{a}$ & $1.17 \mathrm{a}$ & $2.65 \mathrm{a}$ \\
\hline Rotary Hoe & $11.72 b$ & $24.38 \mathrm{a}$ & $57.00 \mathrm{a}$ & $7.62 \mathrm{a}$ & $11.46 \mathrm{a}$ & $38.07 \mathrm{a}$ & $3.56 \mathrm{a}$ & $1.16 \mathrm{a}$ & $2.39 \mathrm{a}$ \\
\hline Leveling Disc Harrow & $12.63 \mathrm{a}$ & $23.21 \mathrm{a}$ & $63.11 \mathrm{a}$ & $7.68 \mathrm{a}$ & $11.82 \mathrm{a}$ & $43.95 \mathrm{a}$ & $3.66 \mathrm{a}$ & $1.10 \mathrm{~b}$ & $2.42 \mathrm{a}$ \\
\hline Disc Plow & $12.46 \mathrm{a}$ & $23.97 \mathrm{a}$ & $57.66 \mathrm{a}$ & $7.97 \mathrm{a}$ & $11.07 \mathrm{a}$ & $38.61 \mathrm{a}$ & $3.64 a$ & $1.08 \mathrm{~b}$ & $2.45 \mathrm{a}$ \\
\hline Manual Weeding & $11.67 \mathrm{~b}$ & $21.38 \mathrm{a}$ & $56.78 \mathrm{a}$ & $6.53 a$ & $10.49 a$ & $39.75 a$ & $3.52 \mathrm{a}$ & $1.07 \mathrm{~b}$ & $2.36 \mathrm{a}$ \\
\hline \multicolumn{10}{|l|}{ Depth of Sowing } \\
\hline $1.5 \mathrm{~cm}$ & $12.16 \mathrm{a}$ & $23.77 \mathrm{a}$ & $59.64 \mathrm{a}$ & $8.29 \mathrm{a}$ & $11.42 \mathrm{a}$ & $40.10 \mathrm{a}$ & $3.63 \mathrm{a}$ & $1.11 \mathrm{a}$ & $2.46 a$ \\
\hline $3.0 \mathrm{~cm}$ & $12.35 \mathrm{a}$ & $23.52 \mathrm{a}$ & $62.29 \mathrm{a}$ & $7.14 \mathrm{a}$ & $11.78 \mathrm{a}$ & $43.36 \mathrm{a}$ & $3.63 \mathrm{a}$ & $1.10 \mathrm{a}$ & $2.40 \mathrm{a}$ \\
\hline $4.5 \mathrm{~cm}$ & $12.45 \mathrm{a}$ & $23.21 \mathrm{a}$ & $64.18 \mathrm{a}$ & $7.95 \mathrm{a}$ & $11.79 \mathrm{a}$ & $44.56 \mathrm{a}$ & $3.68 \mathrm{a}$ & $1.14 \mathrm{a}$ & $2.50 \mathrm{a}$ \\
\hline Source of Variation & \multicolumn{9}{|c|}{ Medium Square } \\
\hline Block & 4.16 & 0.91 & 192.8 & 0.52 & 0.60 & 86,2 & 0.60 & 3.18 & 2.66 \\
\hline Soil Preparation (SP) & $40.0^{* *}$ & $9.44^{\mathrm{ns}}$ & $581.51^{\mathrm{ns}}$ & $7.99^{\mathrm{ns}}$ & $18.9^{\mathrm{ns}}$ & $347.3^{\mathrm{ns}}$ & $15.79^{\mathrm{ns}}$ & $1.807^{*}$ & $11.7^{\mathrm{ns}}$ \\
\hline Error 1 & 5.13 & 5.16 & 223.0 & 2.45 & 6.2 & 143.7 & 1.33 & 0.38 & 4.97 \\
\hline Depth of Sowing (DS) & $3.82^{\mathrm{ns}}$ & $1.18^{\mathrm{ns}}$ & $77.87^{\mathrm{ns}}$ & $5.20^{\mathrm{ns}}$ & $3.9^{\mathrm{ns}}$ & $79.8^{\mathrm{ns}}$ & $3.932^{\mathrm{ns}}$ & $0.525^{\mathrm{ns}}$ & $3.93^{\mathrm{ns}}$ \\
\hline $\mathrm{SP} \times \mathrm{DS}$ & $5.34^{\mathrm{ns}}$ & $4.51^{\mathrm{ns}}$ & $177.60^{\mathrm{ns}}$ & $2.29^{\mathrm{ns}}$ & $9.8^{\mathrm{ns}}$ & $92.0^{\mathrm{ns}}$ & $2.67^{\mathrm{ns}}$ & $1.46^{\mathrm{ns}}$ & $4.63^{\mathrm{ns}}$ \\
\hline Error 2 & 4.64 & 2.62 & 168.78 & 2.37 & 2.64 & 105.0 & 2.674 & 1.50 & 3.95 \\
\hline $\mathrm{CV}(\%)$ & 8.32 & 23.35 & 21.70 & 22.84 & 26.39 & 5.91 & 10.28 & 8.91 & 8.32 \\
\hline
\end{tabular}

Note. Averages followed by distinct letters differ from each other by Scott-Knott test at 5\% of probability. CV $(\%)$ : Coefficient of variation.

** Significant at the 0.01 probability $(\mathrm{p}<0.01)$ by the F-test. * Significant at the 0.05 probability $(\mathrm{p}<0.05)$ by the F-test. NS, not significant $(\mathrm{p}>0.05)$ by F-test.

The factor depth of planting among the variables did not show significant differences between the treatments (Table 5). Experiment made with the corn cultivation under different depths of sowings did not present difference in the variables cob diameter, number of row of grain per spike, where the author reports that the genetic issues of the material presents a strong indication for do not present difference between the applied treatments (Souza, 2016).

Considering the indicated results in (Figure 2A), the method with subsoiling and rotary hoe provided higher productivity. The depth of planting did not show difference between the averages at the level of $(p<0.05)$ by the clustering test (Figure 2B). 

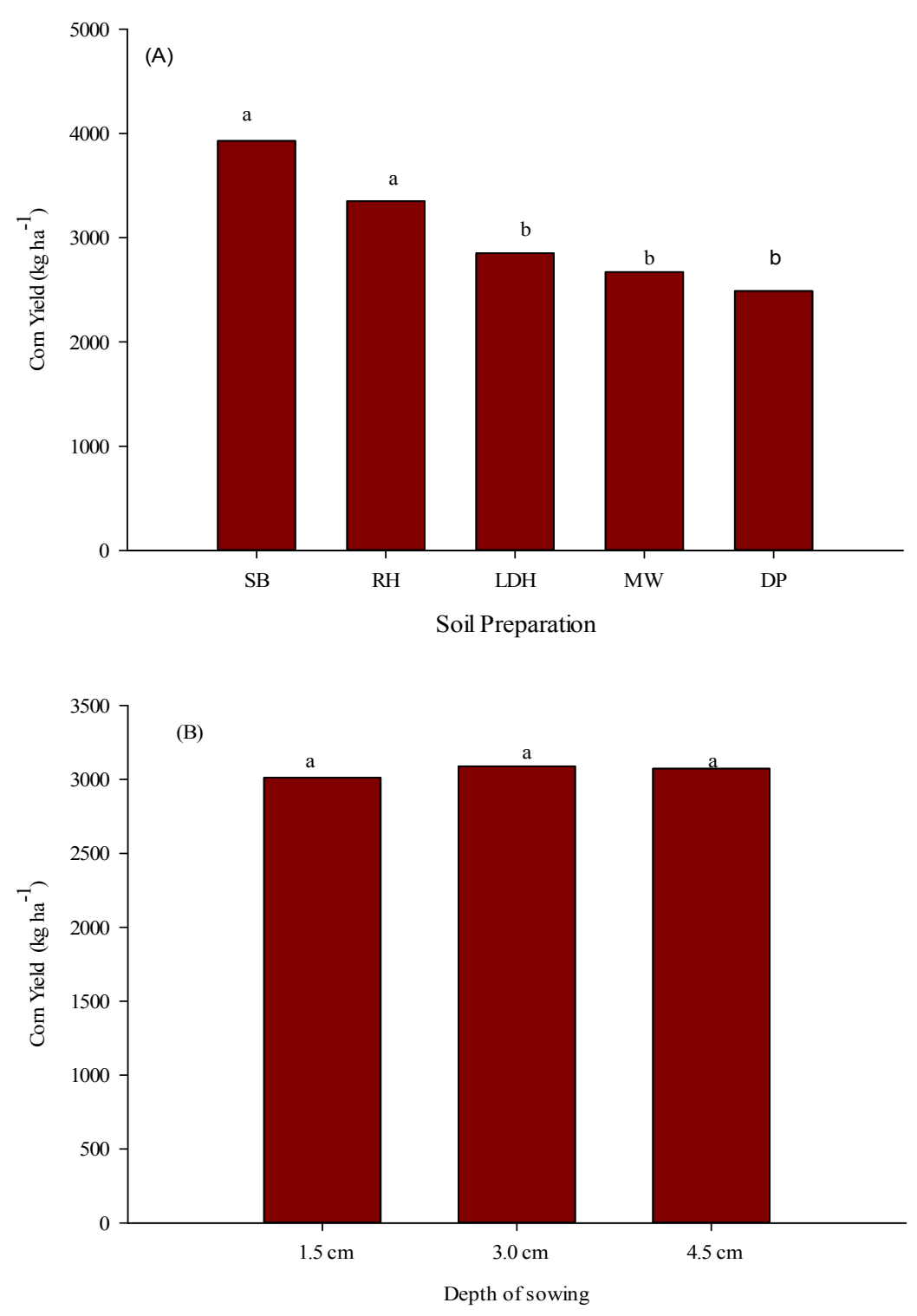

Figure 2. Corn Yield $\left(\mathrm{kg} \mathrm{ha}^{-1}\right)$ as a function of soil preparation methods (A) and depth of sowing (B) in corn cultivation

Note. Averages followed by distinct letters differ from each other by Scott-Knott test at $5 \%$ of probability. Subsoiler (SB); rotary hoe (RH); Leveling disc harrow (LDH); disc plow (DP); manual weeding (MW).

As can be seen in Figure 1A, the methods of soil preparation with subsoiling and rotary hoe presented better results, achieving higher corn yield. According to Cai et al. (2014), subsoiling promotes soil improvement, increase in root length, surface area, dry mass and diameter, and increased the proportion of roots in the 40-80 $\mathrm{cm}$ soil layer. In addition, it showed better accumulation of aerial mass of the plants, increase in grain mass and final increase in corn yield. Liu et al. (2016) concluded that the annual inter-row spring subsoil depth of $50 \mathrm{~cm}$ (AS-50) significantly improved biomass and increased grain yield.

These results found in productivity can be related to the mass variables. As the greater accumulation of plant mass, mainly of the root, has the direct contribution to the better vigor of the plant. Thus, the plant establishes a full development, physiological and morphological, with the extraction of water and mineral salts of the soil to conduct solute translocation for filling the grains.

This result can be related to the fact that the use of agricultural implements improves the physical conditions of the soil, since the rotation tends to reduce soil density and increase soil porosity favoring root growth and 
development. The results showed that soil compaction affected the root growth of corn cultivation, where the disruption of the deeper layers facilitates the expansion of the root system to subsurface layers (Freddi et al., 2009).

\section{Conclusion}

For the mentioned area the study shows that the depth of sowing influences the corn yield if there are compacted layers.

The corn yield presented better yields with the subsoiled and rotary hoe preparation.

\section{References}

Almeida, R. A. S., Tavares-Silva, C. A., \& Silva, S. L. (2010). Desempenho energético de um conjunto trator-semeadora em função do escalonamento de marchas e rotações do motor. Agrarian, 3(7), 63-70. https://doi.org//10.30612/agrarian.v3i7.1086

Bartlett, M. S. (1937). Properties of sufficiency and statistical tests. Proc. R. Soc. Lond. A, 160(901), 268-282. https://doi.org/10.1098/rspa.1937.0109

Berisso, F. E., Schjønning, P., Keller, T., Lamandé, M., Etana, A., de Jonge, L. W., \& Forkman, J. (2012). Persistent effects of subsoil compaction on pore size distribution and gas transport in a loamy soil. Soil and Tillage Research, 122, 42-51. https://doi.org/10.1016/j.still.2012.02.005

Bertolini, E., Gamero, C., \& Benez, S. (2006). Desempenho da cultura do milho em diferentes manejos do solo sobre cobertura vegetal de nabiça (Raphanus raphanistrum L.). Energ. Agric, 21(1), 34-39.

Bottega, E. L., Braido, R., von Linsingen Piazzetta, H., de Oliveira Neto, A. M., \& Guerra, N. (2014). Efeitos da profundidade e velocidade de semeadura na implantação da cultura do milho. Pesquisa Agropecuária Pernambucana, 19(2), 74-78. https://doi.org/10.12661/pap.2014.011

Box, G. E. P., \& Cox, D. R. (1964). Ananalysis of transformations. J. Royal Stat. Soc., 26, 211-252.

Cai, H., Ma, W., Zhang, X., Ping, J., Yan, X., Liu, J., \& Ren, J. (2014). Effect of subsoil tillage depth on nutrient accumulation, root distribution, and grain yield in spring maize. The Crop Journal, 2(5), 297-307. https://doi.org/10.1016/j.cj.2014.04.006

Carvalho Filho, A., Carvalho, L. C., Centurion, J. F., Silva, R. P. D., \& Furlani, C. E. (2006). Efeitos de sistemas de preparo do solo na cultura da soja (Glycine max (L.) Merrill). Engenharia Agrícola, 26(3), 777-786. https://doi.org/10.1590/S0100-69162006000300015

Cravo, M. S., Viégas, I. J. M., \& Brasil, E. C. (2007). Recomendações de adubação e calagem para o Estado do Pará (p. 262). Embrapa Amazônia Oriental, Belém, PA.

Deperon Junior, M. A., Nagahama, H. D. J., Olszevski, N., Cortez, J. W., \& Souza, E. B. (2016). Tillage machinery and compaction level influence on soil physical properties and corn agronomic aspects. Engenharia Agrícola, 36(2), 367-376. https://doi.org/10.1590/1809-4430-Eng.Agric.v36n2p367-376/2016

EMBRAPA (Empresa Brasileira de Pesquisa Agropecuária). (1997). Centro Nacional de Pesquisa de Solos. Manual de métodos de análise de solo (2nd ed., p. 212). Rio de Janeiro, EMBRAPA-CNPS..

EMBRAPA (Empresa Brasileira de Pesquisa Agropecuária). (2010). Sistema de Produção 2: Cultivo do milho (6th ed.). Embrapa Milho e Sorgo, Versão Eletrônica.

EMBRAPA (Empresa Brasileira de Pesquisa Agropecuária). (2013). Sistema brasileiro de classificação de solos (3rd ed., p. 353). Brasília.

Ferreira, D. F. (2011). Sisvar: A computer statistical analysis system. Ciência e Agrotecnologia, 35(6), 1039-1042. https://doi.org/10.1590/S1413-70542011000600001

Foloni, J. S. S., Calonego, J. C., \& Lima, S. L. (2003). Efeito da compactação do solo no desenvolvimento aéreo e radicular de cultivares de milho. Pesq. Agropec. Bras., 38(8), 947-953. https://doi.org/10.1590/ S0100-204X2003000800007

Francetto, T. R., Alonço, A. D. S., Bellé, M. P., Franck, C. J., \& Carpes, D. P. (2015). Comportamento operacional de associações entre sulcadores e discos de corte para sistema de semeadura direta. Engenharia Agrícola, 35, 542-554. https://doi.org/10.1590/1809-4430-Eng.Agric.v35n3p542-554/2015 
Freddi, O. S., Carvalho, M. P., Veronesi Júnior, V., \& Carvalho, G. J. (2006). Produtividade do milho relacionada com a resistência mecânica à penetração do solo sob preparo convencional. Engenharia Agrícola, 26(1), 113-121. https://doi.org/10.1590/1809-4430-Eng.Agric.v36n2p367-376/2016

Freddi, O. S., Centurion, J. F., \& Almeida, C. X. (2009). Compactação de um latossolo vermelho de textura argilosa afetando o sistema radicular e a produtividade do milho. Revista Ceres, 56(5), 655-665.

Grotta, D. C. C., Lopes, A., Furlani, C. E. A., Branquinho, K. B., Reis, G. N., \& Silva, R. P. (2008). Subsolador: Avaliação do desempenho em função da velocidade de trabalho e espaçamento entre hastes. Acta Scientiarum. Agronomy, 26(1), 21-26. https://doi.org/10.4025/actasciagron.v26i1.1951

Guaman, V., Båth, B., Hagman, J., Gunnarsson, A., \& Persson, P. (2016). Short time effects of biological and inter-row subsoiling on yield of potatoes grown on a loamy sand, and on soil penetration resistance, root growth and nitrogen uptake. European Journal of Agronomy, 80, 55-65. https://doi.org/10.1016/j.eja. 2016.06.014

Instituto de Economia Agrícola. (2017). Milho: Perspectiva da safra internacional. IEA.

Liu, Z., Qin, A., Zhao, B., Ata-Ul-Karim, S. T., Xiao, J., Sun, J., \& Duan, A. (2016). Yield response of spring maize to inter-row subsoiling and soil water deficit in northern China. PloS One, 11(4),1-15, https://doi.org/10.1371/journal.pone.0153809

Oliveira Filho, F. X., Miranda, N. D. O., De Medeiros, J. F., Da Silva, P., Mesquita, F. O., \& Costa, T. K. (2015). Zona de manejo para preparo do solo na cultura da cana-de-açùcar. Revista Brasileira de Engenharia Agricola e Ambiental, 19(2), 186-193. https://doi.org/10.1590/1807-1929/agriambi.v19n2p186-193

Oliveira, F. J., Farias, P. R., Silva, A. G., \& Rodrigues, K. C. (2016). Distribuicão espacial da leprose dos citros na Amazônia Oriental. Revista Ciência Agronômica, 47(1), 56-68. https://doi.org/10.5935/1806-6690. 20160007

Prado, R. M., Coan, O., \& Villar, M. L. P. (2002). Compressão do Solo e Profundidade de Semeadura na Emergência e no Crescimento Inicial da Cultura do Milho (Zea Mays L.). Revista Científica Eletrônica de Agronomia, 1(2), 1-6.

Ros, V. D. V., Souza, C., Vitorino, A. C., \& Rafull, L. Z. (2011). Oxisol resistence to penetration in no-till system after sowing. Revista de Engenharia Agrícola, 31(6), 1104-1114 https://doi.org/10.1590/S0100-691620110 00600008

Rossetti, K. V., \& Centurion, J. F. (2013). Sistemas de manejo e atributos físico-hídricos de um Latossolo Vermelho cultivado com milho. Revista Brasileira de Engenharia Agrícola e Ambiental, 17(5), $472-479$. https://doi.org/10.1590/S1415-43662013000500002

Santos, L. B. D., Castagnara, D. D., Bulegon, L. G., Zoz, T., Oliveira, P. S. R., Goncalves, A. C., \& Neres, M. A. (2014). Substituição da adubação nitrogenada mineral pela cama de frango na sucessão aveia/milho. Bioscience Journal, 30(3), 272-281.

Shapiro, S. S., \& Wilk, M. B. (1965). An analysis of variance test for normality (complete samples). Biometrika, 52, 591-611. https://doi.org/10.1093/biomet/52.3-4.591

Silva, A. G., Boiça Junior, A. L., Farias, P. R. S., \& Barbosa, J. C. (2011a). Infestação da mosca-negra-dos-citros em pomares de citros em sistema de plantio convencional e agroflorestal. Revista Brasileira de Fruticultura 33(1), 53-60. https://doi.org/10.1590/S0100-29452011005000038

Silva, A. R., Dias Junior, M. D. S., \& Leite, F. P. (2011b). Avaliação da intensidade de tráfego e carga de um forwarder sobre a compactação de um Latossolo Vermelho-Amarelo. Revista Árvore, 35(3), $547-554$. https://doi.org/10.1590/S0100-67622011000300017

Silva, M. A. A., Azevedo, L. P., Saad, J. C. C., \& Michels, R. N. (2013). Efeito de dois sistemas de manejo do solo nas propriedades físico-hídricas, desenvolvimento radicular e produtividade do milho irrigado. Irriga, 18(3), 486. https://doi.org/10.15809/irriga.2013v18n3p486

Silva, V. R., Reinert, D. J., \& Reichert, J. M. (2000). Resistência mecânica do solo à penetração influenciada pelo tráfego de uma colhedora em dois sistemas de manejo do solo. Ciência Rural, 30(5), $795-801$. https://doi.org/10.1590/S0103-84782000000500009

Sousa, S. F. G., Silva, P. R. A., Dias, P. P., da Siva Correia, T. P., \& Giroti, J. F. (2016). Avaliação da cultura do milho semeada em diferentes profundidades. Energia na Agricultura, 31(2), 148-153. https://doi.org/ 10.17224/EnergAgric.2016v31n2p148-153 
Souza, F. H. (2017). Desempenho das culturas de soja e milho e atributos físicos do solo em diferentes sistemas de preparo e retomada do sistema de plantio direto (67f. Tese, Doutorado em Sistemas de Produção, Universidade Estadual Paulista Faculdade de Engenharia Campus Ilha Solteira, Ilha Solteira).

Souza, S. F. G. de. (2016). Depths of sowing and spacing of plants to the corn crop (59 f. Tese, Doutorado em Agronomia/Energia na Agricultura, Faculdade de Ciências Agronômicas, Universidade Estadual Paulista, Botucatu).

Streck, C.A., Reinert, D. J., Reichert, J. M., \& Kaiser, D. R. (2004). Modificações em propriedades físicas com a compactação do solo causada pelo tráfego induzido de um trator em plantio direto. Ciência Rural, 34(3), 755-760. https://doi.org/10.1590/S0103-84782004000300016

Suzuki, L. E. A. S., \& Alves, M. C. (2004). Produtividade do milho (Zea mays L.) influenciada pelo preparo do solo e por plantas de cobertura em um Latossolo Vermelho. Acta Scientiarum Agronomy, 26(1), 61-65. https://doi.org/10.4025/actasciagron.v26i1.1958

Valicheski, R. R., Grossklaus, F., Stümer, S. L. K., Tramontin, A. L., \& Baade, E. S. A. S. (2012). Desenvolvimento de plantas de cobertura e produtividade da soja conforme atributos físicos em solo compactado. Revista Brasileira de Engenharia Agrícola e Ambiental-Agriambi, 16(9), 969-977. https://doi.org/10.1590/S1415-43662012000900007

Wolkowski, R., \& Lowery, B. (2008). Soil compaction: Causes, concerns and cures. Cooperative Extension Learning Store, Madison.

\section{Copyrights}

Copyright for this article is retained by the author(s), with first publication rights granted to the journal.

This is an open-access article distributed under the terms and conditions of the Creative Commons Attribution license (http://creativecommons.org/licenses/by/4.0/). 